Raphael M. Dayanov

Lecturer of the Architecture Department

Repin State Academic Institute of Painting, Sculpture, and Architecture,

Architect-restorer of the highest category,

Honored Builder of the Russian Federation,

Honorary Architect of the Russian Federation,

Honorary Restorer of St. Petersburg,

Director of the Liteinaya Chast-91 Architectural Bureau

e-mail: raf_dayanov@mail.ru

Saint Petersburg, Russia

ORCID 0000-0002-8950-0698

Anna M. Zalmanzon

Researcher at the Baltic Restoration Collegium, e-mail: zalmanzon@mail.ru

Saint Petersburg, Russia

ORCID 0000-0002-5099-4301

\title{
THE HOUSE OF FRIDERICI AS A LOST ELEMENT OF THE BACKGROUND DEVELOPMENT IN TSARSKOYE SELO
}

Summary: The paper considers the history of the construction of lost element of the background building in Tzarskoe Selo - by the modern address Saints-Petersburg, town of Pushkin, 21, Krasnaya Zvezda street. This house was built in 1938 and was many times rebuilt and finally completely lost its initial appearance, but is still on the place of its construction. On the base of archival researchers, we manage to reveal the sequence of its reconstructions and architectural features of the building in the various periods of its existence. We have determined names of architects who participated in design and construction of the house (I.A. Rezantzev, A. A. Ton) and also found names of its owners in different periods. It was thought that widow Frideretzi was the first owner of the house. Our studies show that there were at least two owners before her. Genealogical studies allowed collecting information about Elisabeth Frideritzi, who was in fact the last but not the only owner of the house in the prerevolutionary period. The survived drafts and pictorial representations, published for the first time in our arti-

The house at 21 Krasnaya Zvezda Street in Pushkin is one of the few surviving planning elements of the original terraced housing development of Tsarskoye Selo. In her book, G.Semenova, who was the first to introduce information about the house cle, help to produce detailed description of the building. Special attention of the authors paid to the reconstruction to the design of architect V.D. Sokolov in $1909-1910$. The fate of the background buildings in town of Pushkin in $20^{\text {th }}$ century turned tragically. During the World War II the town was occupied by Nazi. $85 \%$ of buildings were destroyed completely, and the rest needed serious renovation. In 1947 the former house of Frideritzes was reconstructed in the style of Soviet classicism, and its initial appearance was distorted. The paper gives the critical description of the architecture of the building. In the 1960 the building has had the capital repair, which changed its internal plan. The building now keeps size and scale of the initial background building, other elements, which define its city planning significance are lost. The object lost its authentic appearance and therefore cannot be considered object of history of culture.

Keywords. Frideritsi house, background buildings, Tzarskoe Selo, architect A. A. Ton, architect I. A. Rezantsev, architect V. D. Sokolov, historical objects.

into scientific circulation, indicated that the house was built by architect A.Ton in 1838 for the wife of an officer of a hussar regiment, E.Friderici. In 1909, it was rebuilt by architect V.Sokolov for A.Grigorieva. At the same time, according to the researcher, 
the house has retained the character of architecture in the style of late classicism to this day. [15]. There is no other data on the house in the literature. This information is given in all the local history literature published after the publication of the book by G.Semenova and entered into the KGIOP (Committee for State Control, Use, and Protection of Historical and Cultural Monuments of St. Petersburg) records.

In the course of the historical and archival research undertaken to study the house's detailed history, facts were established that clarify the data on the owners and reconstruction of the building. In the archives, drawings were found that completely change the idea of what was lost as a result of destruction during the years of occupation and subsequent restoration, the historical appearance of the building in the summer residence period of Tsarskoye Selo.

The background development of Tsarskoye Selo was almost completely lost during the civil war, the Great Patriotic War, and the occupation. Reconstructed based on archival data, the house's appearance in question was a typical example of the terraced housing development of Tsarskoye Selo in its summer residence period of the late $19^{\text {th }}$ - early $20^{\text {th }}$ centuries. New data on the building's architecture make it possible to supplement the idea of the appearance of the quarters of the terraced housing development of Tsarskoye Selo that has survived only in a few images. The discoveries made in the course of the research restore the truth about the original appearance of the almost wholly lost building, which in its present, unpresentable appearance, recognized by the literature as the original, distorts the idea of the background development of the residential quarters of the royal residence.

The place for building the house, located on a site with a current address 21 Krasnaya Zvezda Street, Pushkin, Petersburg, was assigned in the 1830s. The site was listed on Stesselskaya Street, the $3^{\text {rd }}$ part of Tsarskoye Selo - Sofia Suburb, planned according to the project of architect A.Gildenbrandt, approved in 1832. [14] According to architect A.Gildenbrandt's plan of the quarters of 1832, the development with typical houses on the site of the former city of Sofia was supposed to be based on model projects. The front house on the site was built in 1838. Completely rebuilt and having lost its historical appearance, this original house has been preserved to this day in its original place.
Based on the newly found archival materials, the sequence of owners of this site is established. The revised data refute the earlier accepted in the literature the attribution of the original building as belonging to E.Friderici, the wife of an officer. Archival materials unambiguously indicate that the wife of the titular counselor, Olga Grigorieva, was the first owner of the site and the purchaser of the front house.

The next in time after Grigorieva, the wife of the major, Maria Mikhailova, about whom the information has been preserved, was the site owner. [17, p.71.]

The Mikhailov family owned the site until December 9, 1906, when it passed to pharmacist Alfons Deringer from Olga Mikhailova, the daughter of Lieutenant General, at a public auction. On February 3, 1907, Deringer sold the site with all the buildings to E.Friderici, the staff captain's wife. [11]

Based on the study of the literature on genealogy, the personality of Friderici was established. In the literature, the name was unreasonably assigned to the first owner of the site. In the tsarist period, this was the last and not the first owner of the site Elizaveta Friderici, born Duchess Ruffo (1887-1940), the daughter of Princess Natalya Meshcherskaya and her husband, knight of the Order of Malta, Italian duke Fabrizio Sasso-Ruffo. In the first marriage (1907-1916), she was married to the Colonel of the Guards, Alexander Friderici, in the second (since 1918) - to the prince of the imperial blood, Andrey Alexandrovich Romanov. [13, p. 139.]

Around 1839, the first owner of the site, the wife of the titular counselor, Olga Grigorieva, built a one-storey house with a mezzanine on seven axes on the front facade on the site. [4]

According to the project, a wooden one-storey front house on seven axes with a mezzanine was to be built on an elongated rectangular site. Galleries, stretching along the entire facade, adjoined the main house from the courtyard side. Further, in the courtyard's direction, a rectangular kitchen and toilet were added to the galleries. On the site, in the depths, there was a garden with a central wooden, square-shaped gazebo. In the center of the site, there were sheds with stables, manure and cesspool pits, and a toilet near the garden. The place was separated from the street by a blind fence with a gate.

Under a pitched roof with a central risalit crowned with a triangular pediment, the house's front facade is close in composition to classicism model projects; however, the emerging romanticism's influence can be traced in the details. 


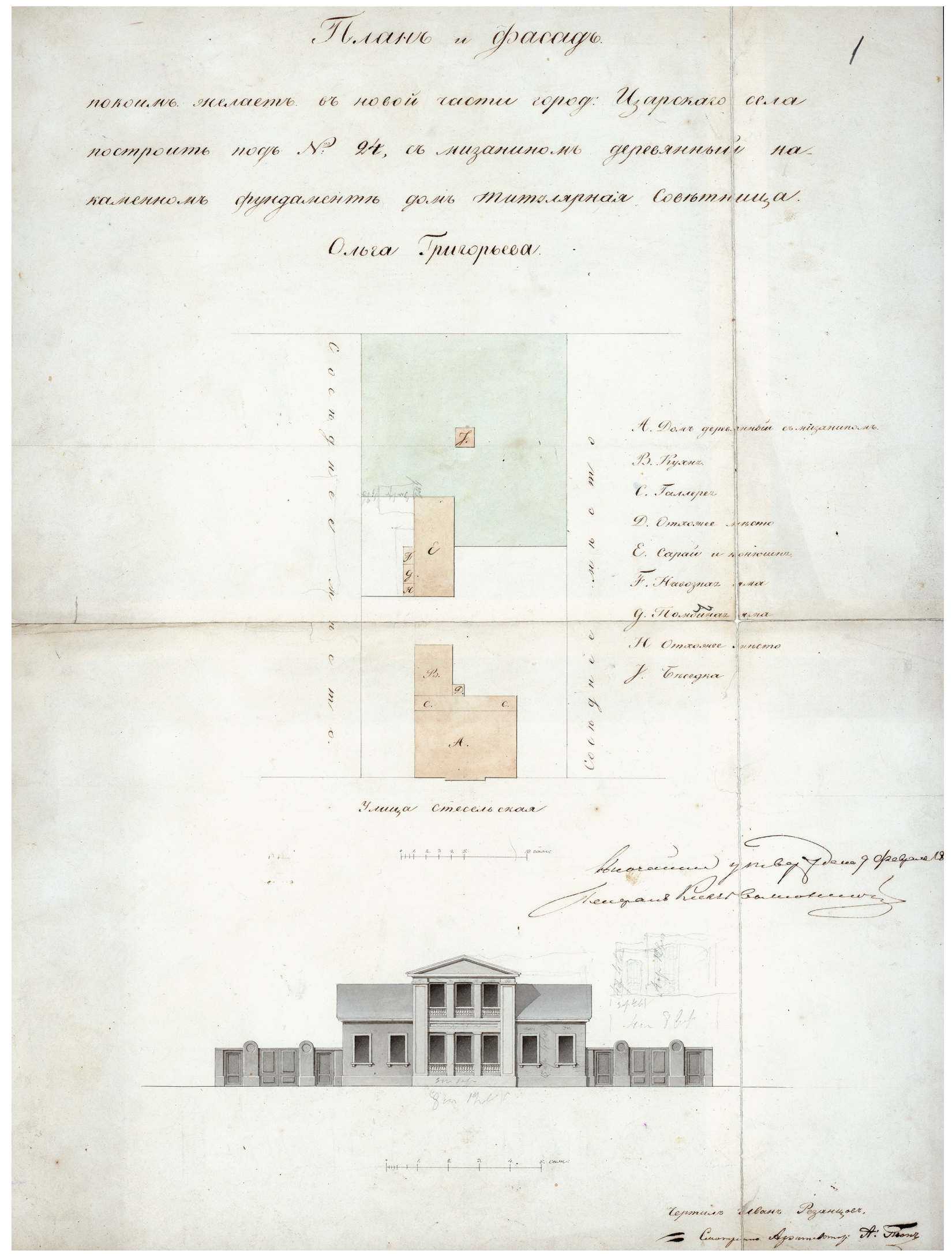

Architect I.Rezantsev. Architect A.Ton. The House of Titular Counselor Olga Grigorieva. A plan and facade. 1838, RGIA. F. 485. Inv. 3. f.1021. L.1.

The pilasters decorating the edges of the risalit are stylized, paneled, and end with a slab instead of a capital. Vertical and horizontal divisions fractionally partition the risalit area. In addition to corner pilasters, the risalit is decorated with narrow pilasters in the partitions at each floor level. The floors are divided by a wide panel with an emphasized plastic design: a niche panel framed by an addition- 


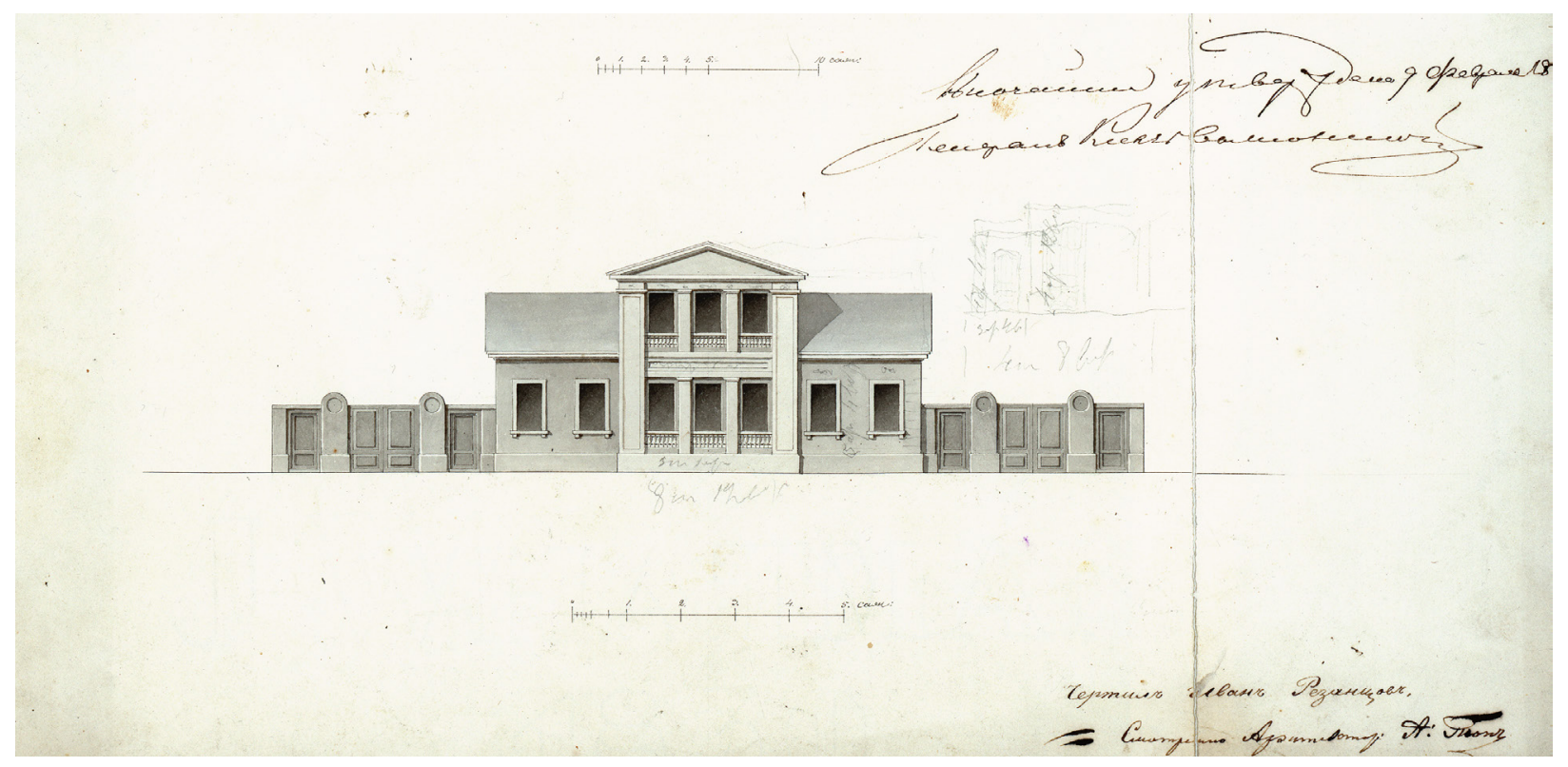

Architect I.Rezantsev. Architect A.Ton. The House of the Titular Counselor Olga Grigorieva. Fragment. 1838 RGIA.

F. 485.Op. 3. D.1021. L.1.

al ledge. The under-window spaces are decorated with rows of balusters. The facade is crowned with a profiled cornice. A smooth frieze is located under the pediment.

The drawing retained the edits of one of the reviewers. Someone (most likely A.Ton) did not agree with the inter-floor panel; it is crossed out. It was proposed to decorate the smooth frieze with an ornament and change the pattern of the fence and the shape of the gate.

The project was approved on February 9, 183(?). The last digit in the year is cut off. According to another document from the archive, the house was built by 1839 . This case refers to the inspection of furnaces designed by Charlemagne in this house in January 1840. [5]

In the literature, the authorship of the building is attributed to architect A.Ton. In the design drawing of the building, there is no indication of his authorship. The inscription on the project says that it was "Drawn by Ivan Rezantsev", and Ton checked it: "Viewed by architect A.Ton". This formulation allows us to assert that architect I.Ryazantsev used a model project, which he took as a basis for the design. As the leading architect of Tsarskoye Selo, A. Ton oversaw the house's design and all other private developments in the city and agreed on the design.

In 1858, on a site separated from the street by a fence, there was an original one-storey wooden house on a stone foundation. [17, p.71.]

During the Mikhailov family's ownership, several service wooden buildings were built on the site. [11]
The front one-storey wooden house with a mezzanine was preserved in its original form.

Pharmacist Alfons Deringer, who became the owner of the site after the daughter of Lieutenant General, Olga Mikhailova, on December 9, 1906, owned it for only two months and then sold the site with all the buildings to E.Friderici, the wife of the head captain.

In 1909, by E.Friderici's order, a second floor was added to the front house, an extension was made to it from the side of the yard. The author of the project is architect V.Sokolov (1889 - 1955), in the future - a famous Soviet architect. [12]

During the restructuring, the northern courtyard part of the front house (the gallery with a kitchen) was dismantled; in their place, a new two-storey building was constructed with a ledge towards the eastern facade, designed to expand the apartments and organize a second staircase. By the time of the reconstruction, the building entrance and the stairs were arranged from the western facade. According to V.Sokolov's project, the second staircase to the apartments was organized from the eastern facade's side. In the interiors, local redevelopments were made with the organization of utility rooms and additional bathrooms, as well as with the division of apartments into the master's part (at the front facade) and the servants' area (at the courtyard facade, with an entrance from the eastern facade).

The facade was rebuilt with neoclassical decoration. The plastered facade, which retained the previous building's structure with a central part high- 


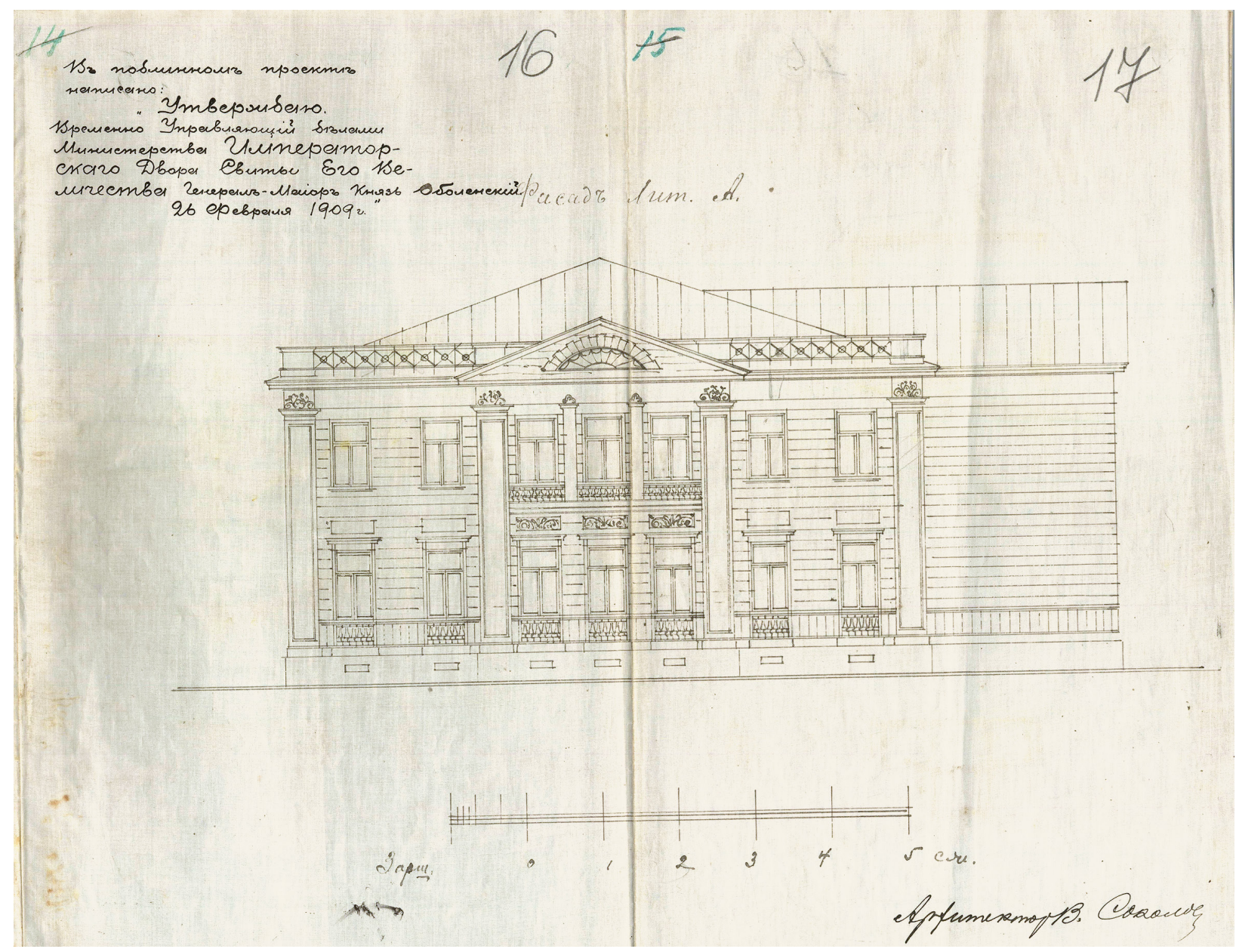

Architect V.Sokolov. The House of the Wife of the Head Captain of the Life Guards of the His Majesty Hussar Regiment, E.Friderici. Facade. 1909, TsGIA St.Petersburg, F. 1546. Inv. 5. f. 1809. L. 16-17.

lighted by pilasters under the triangular pediment, had a rich design. The small scale of the facade decoration gave the building a "dacha" look characteristic of the background development of Tsarskoye Selo.

From the previous construction, the architect retained the central risalit under the triangular pediment, decorated with paneled pilasters in the corners, thin pilasters between the second floor's windows in the risalit area, and the decoration of window-sill niches with rows of balusters. The architect also decorated the edges of the front facade with pilasters with panels. He added stylized ornamental capitals to the design of all pilasters. In the space between the windows of the first and second floors, the architect added rectangular panels, smooth in the facade's side parts, and ornamented in the risalit. A semicircular attic window under a high roof, decorated with rustication, a roof fencing made of metal grilles of geometric ornament between the posts, plaster imitating the cladding of a wooden house, completed the new chamber look of the country house in the character of neoclassicism. Thus, when rebuilding the facade, the architect used not only its composition, set by the example of classicism, but also the most interesting decorative elements of the previous building: paneled pilasters, rows of balusters in window niches. There is continuity in the facade's architecture; however, the romantic principle is reinforced in the interpretation. Using simple ways that did not require significant alterations, the architect managed to reinterpret the facade's architecture, ultimately moving away from semi-official classicism and changing its perception.

The fact that the front facade's drawing was adopted in 1914 by the Petrograd Provincial Bank as a document for real estate appraisal, and the loan was approved and issued [11, L.14-15] indicates that the presented design was made. The house's facades were plastered, which was recorded by the house's inspection report for a mortgage. [11, L.8]

Since wood was a cheaper material than brick, this technique provided the owner with cost savings while creating the complete illusion of a rich stone house. 


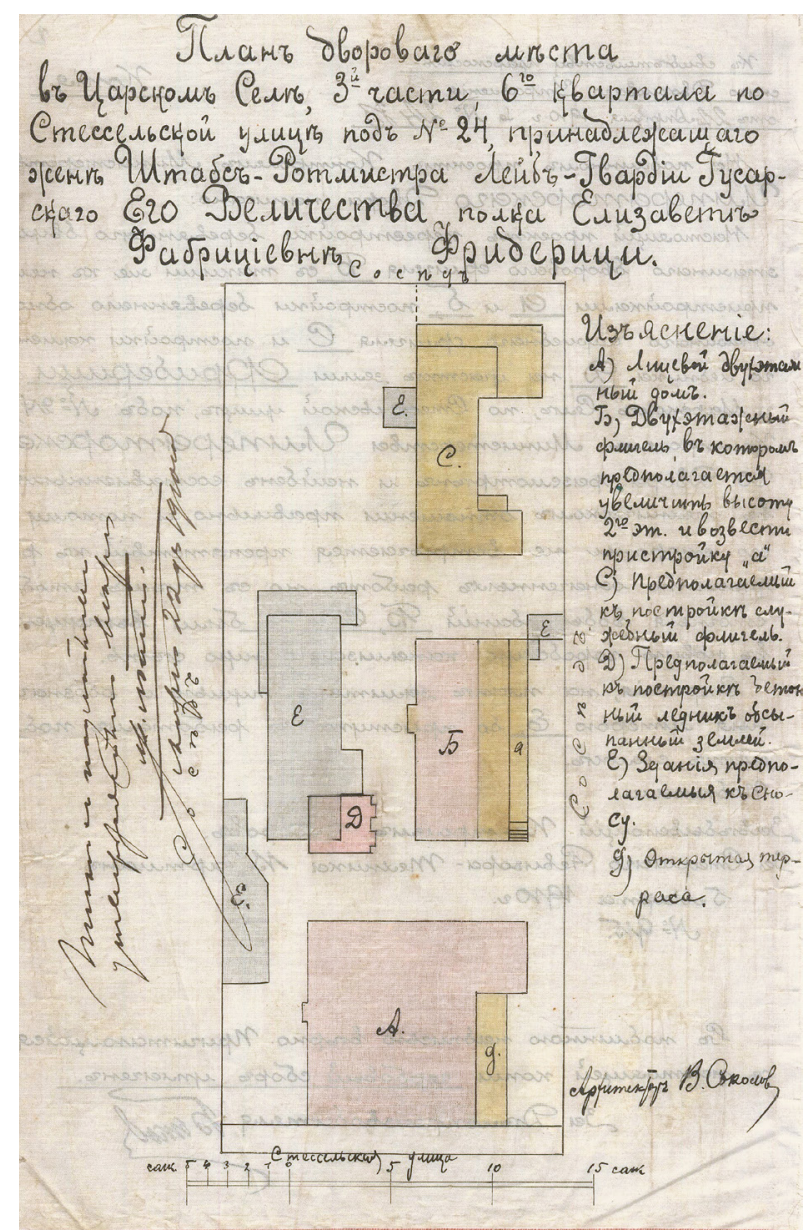

III.4. Architect V.Sokolov. House of the Wife of the Head Captain of the Life Guards of the His Majesty Hussar Regiment, E.Friderici. Site plan. 1910 TsGIA St.Petersburg, F. 1546. Inv. 5. f. 1809. L. 2

By the time of the restructuring, a garden with a gazebo, a shed with a stable remained on the site, and new outbuildings and a wooden glacier were also built. [12, L.3]

In 1910, a second floor and an annex were added to one of the new buildings - a wooden courtyard wing behind the front building (eastern). The facades of the wooden building were covered with planks. The architect designed the facades of the wing in the neo-Russian style. At the same time, a new service one-storey log wing (with a residential apartment) with a mezzanine was built.

The elegant front house in the style of romantic neoclassicism and the wooden courtyard wings in the neo-Russian style were designed to create a single nostalgic ensemble of a "manor in miniature".

The site with buildings was mortgaged in the St. Petersburg Regional Provincial Bank in 1914. The description for the deposit stated that all the buildings had been built about six years ago, they were durable. In the report of the architect who evaluated the buildings, the exceptional durability of the construction and the solidity of the finishing of all houses were noted, which made it possible to evaluate them much more expensive than the usual mortgage value. [eleven]

In the first half of the $20^{\text {th }}$ century, the site's development was preserved; a front house and two outbuildings, erected in 1909-1910, were there.

During the February 1917 coup, the house owner, E.Friderici, ended up in Crimea, where she went after her lover, Grand Duke Andrei Alexandrovich. In 1918, the couple left Russia. [18]

During the civil war, the background development of Tsarskoye Selo, which had been captured by Yudenich's army for three days, began to be lost. It was then that a large number of residential buildings in the city burned down. Anna Akhmatova wrote about this event in the unfinished poem Russian Trianon:

Vse zanyalis' voyennoy suyetoyu,

I ot pozharov sdelalos' svetlo.

I tol'ko yug byl zalit temnotoyu.

Na moy vopros, s svyashchennoy prostotoyu

Skazal sosed: «Tam Tsarskoye Selo.

Ono vchera, kak svechka, dogorelo».

I sprashivat' ya bol'she ne posmela

[Everyone was busy with the military bustle,

And it became bright from the fires.

And only the south was filled with darkness.

To my question, the neighbor said

with sacred simplicity: "There is Tsarskoe Selo.

It burned out like a candle yesterday."

And I didn't dare to ask anymore.] [16]

The city was captured by German troops on September 18, 1941, during the Great Patriotic War. An extended period of occupation began. The invaders destroyed and damaged many structures of the palace ensemble and removed works of art.

The civilian population and residential areas were severely affected by the actions of the occupiers. Almost all city residents were moved to camps, taken to work in Germany, or killed. Houses became empty in Pushkin. As a result of the occupation during the Great Patriotic War, Pushkin residential buildings were entirely lost by $85 \%$, the remaining $15 \%$ of residential buildings were seriously damaged and required "major repairs". [7, L. 27]

The front house at St. Krasnaya Zvezda 21 was also severely damaged during the war. It is known from the documents that the pre-war owner of the house, Vasily Chekulaev, lost a 5000sq.m. residen- 


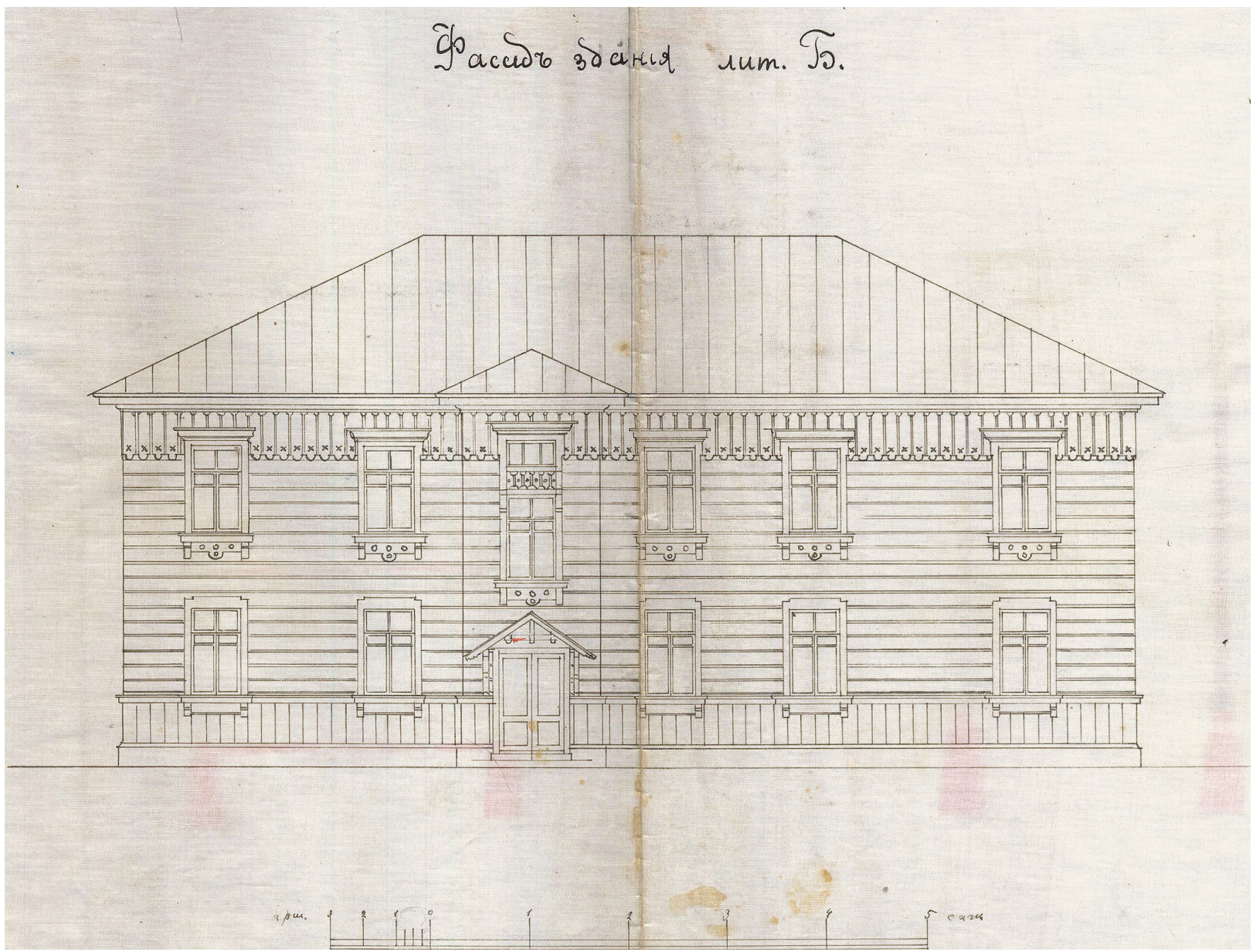

III.5. Architect V.Sokolov. The House of the Wife of the Head Captain of the Life Guards of the His Majesty Hussar Regiment, E.Friderici. The facade of the outbuilding. 1910 TsGIA St.Petersburg, F. 1546. Inv. 5. f. 1809. L.8-9.

tial building, an outbuilding, a horse, a pig, and poultry during the occupation of Pushkin. Losses in residential buildings and outbuildings on the site were expressed in the amount of 430,000 rubles. [10, L. 54-54]

The courtyard wings were destroyed, as evidenced by the site plan of 1948 , which recorded foundations in the place of pre-revolutionary courtyard buildings that coincided in configuration with the buildings on the 1914 plan. [1]

After the war, in 1947, the dilapidated house was restored.

In the title list of the capital construction of the Pushkin District Executive Committee in 1947, the house at St. Krasnaya Zvezda 21 is listed as a capital construction project with an estimated cost of 22.5 thousand rubles and a completion date in the second quarter of the year. [8, L.102-102]

The restored residential building was taken on the balance sheet of the Production Repair and Operational Association of the Pushkin District Executive Committee on March 1, 1947. [3]
The facades of the restored house were decorated in the spirit of Soviet classicism. The Soviet understanding of the style is characterized by the use of decorative details of classicism in isolation from their architectonic meaning: the panel in the upper part of the facade merges with the upper line of the platbands, the keystones above the windows of the second-floor cover the entablature area, rustication along the edges of the risalit is made only at the level of the second floor, semicircular niches above the windows of the first floor are simultaneously interpreted as archivolts; however, at the same time their abutments do not rest on anything, they are "suspended" in the partitions. The niches vary in size, as well as the partitions below them between the central windows. The system is not seen in the side facades' design: the windows are of different sizes and proportions, there are alterations of the position in the axes, there is a substantial discrepancy in the rhythm of the partitions and openings.

The calm main facade of the Soviet era with an orientation towards semi-official classicism contrasts sharply with the design of the historical facades of 


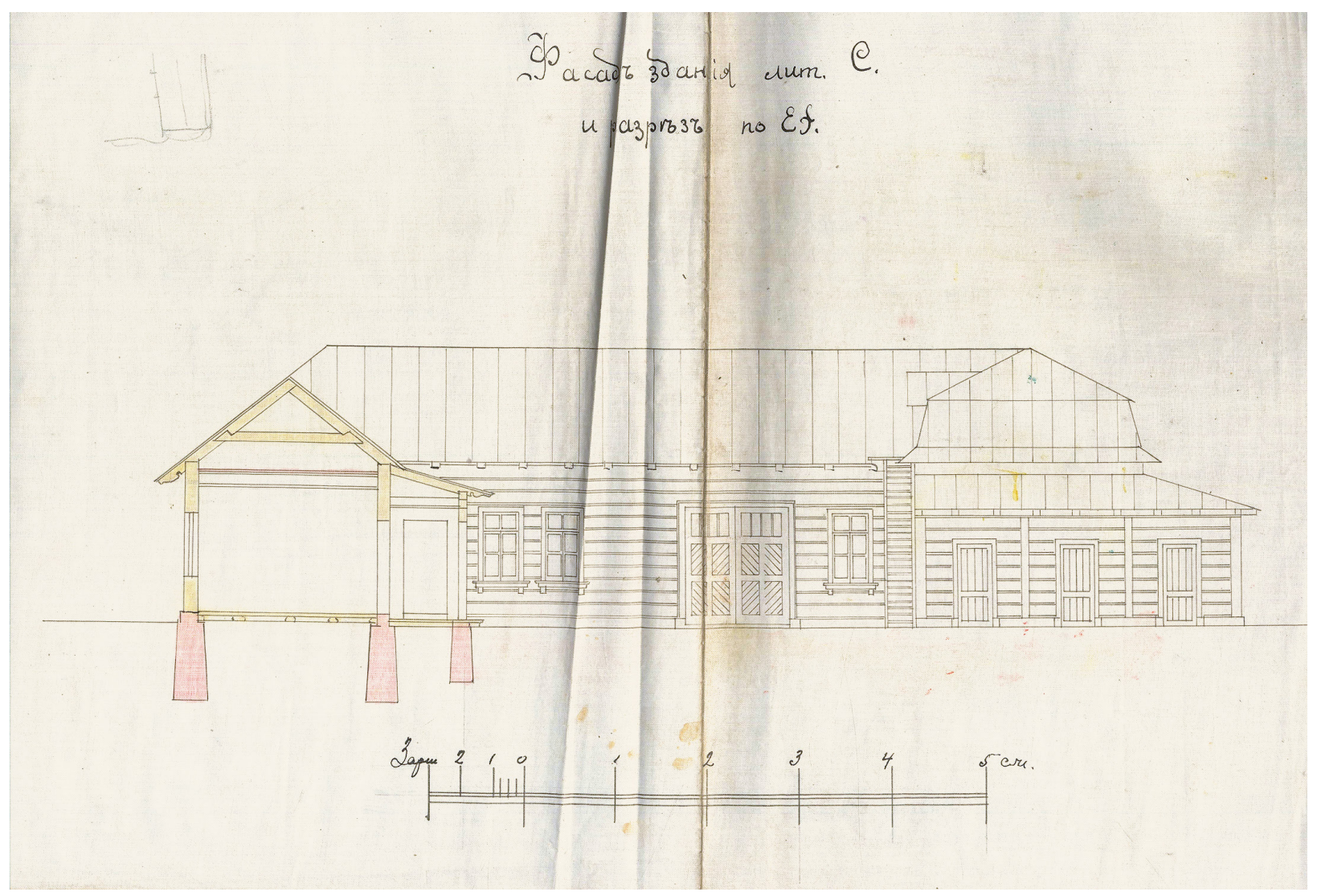

III.6. Architect V.Sokolov. House of the wife of the Head Captain of the Life Guards of the His Majesty Hussar Regiment, E.Friderici. The facade of the outbuilding. 1910, TsGIA St.Petersburg, F. 1546. Inv. 5. f. 1809. L.10-11.

1839 and 1909, in which the methods of softening and romanticizing the appearance of a private country house were successively used.

In fact, the design of the Soviet facades of the house in question cannot even be attributed to classicism; the understanding of the style invested in their creation is too superficial and distorted. From the documents of the post-war restoration of Pushkin houses, it is known that after the renovation, the houses were decorated according to standard designs. [9, L.14.]

Based on the data from disclosure statements, a complete renovation of the house was carried out in 1960. The surviving documents indicate that the repair consisted of replanning. The porch on the eastern facade was demolished; apartments were planned out in the place of the vestibule and the staircase. Judging by the plans of 1960, the historical layout of the house was completely lost during the reconstruction. The house is divided into several corridor-type apartments, while the original historic building had an enfilade layout. [2]

Structural reinforcement was not carried out in 1960. This can be judged based on the data from a survey of building structures carried out 24 years later. In 1984, the Lenzhilproekt Institute, based on the survey results, issued a conclusion on the house's non-repairability and recommended it for disassembly. [6]

The town planning value of the house in question is determined by the fact that the building retains the historical background development scale. The rest of the factors of its town planning significance have been lost. Except for the partially preserved front house in question and a concrete glacier, the site has lost its historical buildings. Historical land surveying has not survived. The front building is preserved in a highly distorted form. Its external appearance in the spirit of Soviet state classicism gives a distorted idea of the background development in Tsarskoye Selo. The house reflects neither the imperial period of the model building of the era of Nicholas I nor the age of the "dacha boom" with a cozy dacha mansion in the neoclassical style.

The building retains the basic composition techniques of the front facade of the historical building: the number of axes (seven), the location of the central risalit, and the shape of the crown - a triangular pediment. The plan and the dimensions of the facades refer to the period of reconstruction in 


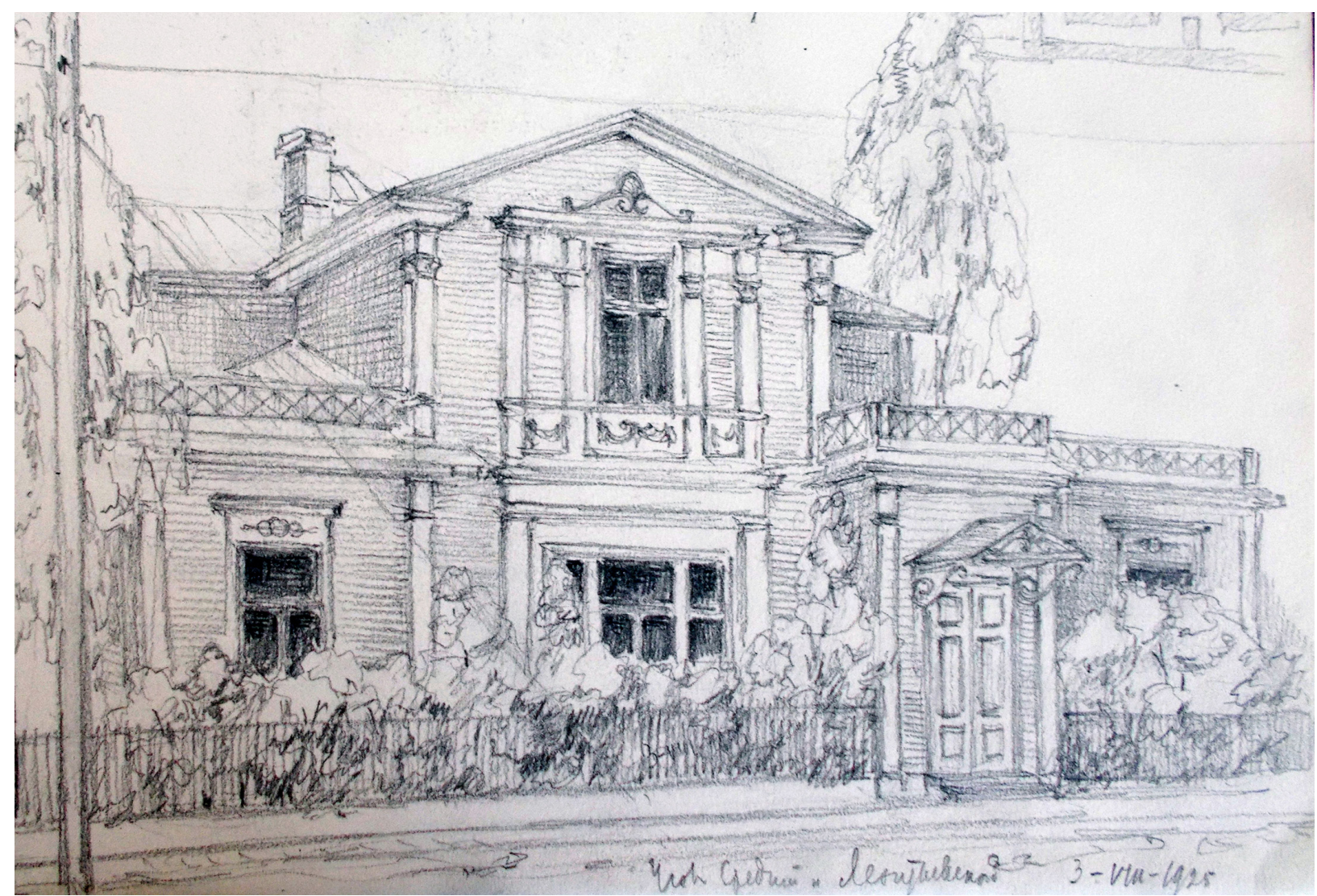

III.7. The Facade of House Number 21 on the St. Krasnaya Zvezda in Pushkin. Photo, 2018.

1909 when the original building, built according to a model project in 1838-39, was rebuilt from the side of the courtyard facade, expanded with a rectangular protrusion on the east side and a second floor was added to it.

The plastered facade, which retained the previous building's structure with a central part highlighted by pilasters under the triangular pediment, had an original architectural design. The small scale of the facade decor gave the building a "dacha" look typical for the background development of Tsarskoye Selo at the beginning of the $20^{\text {th }}$ century. When rebuilding the facade, the architect used the composition of the facade, set by the example of classicism, and the most interesting decorative elements of the previous building: paneled pilasters, rows of balusters in window niches. In the facade's architecture, there is a continuity with the original building; however, the romantic principle is enhanced in the interpretation. Thus, as an element of the background development of Tsarskoye Selo, the rebuilt house was a type of provincial mansion, close in architecture to the two-storey country houses and small mansions that prevailed in the development of Tsarskoye Selo at the beginning of the $20^{\text {th }}$ century.
The current front facade was the result of the reconstruction of the house after the war in 1947. As a result of the destruction of the house and its subsequent restoration, the facade's most expressive elements were lost, softening the perception of strict classicism and giving the facade features of romanticism.

During the house's reconstruction, the roof's shape and height were changed, the attic floor was not restored. As a result of the restoration work and numerous subsequent redevelopments, the house's historical layout was lost.

Thus, the building in question has lost its value characteristics: the original architecture of the facades, layout, height dimensions.

Despite the preservation of some historical characteristics (the scale of the building and the compositional techniques of the front facade), the building cannot be considered a trustworthy source of information about the development of culture, since as a result of destruction during the war years and subsequent restoration, it lost its true historical appearance. With an ugly facade of the Soviet period, the currently existing front house distorts the idea of terraced housing development in Tsarskoye Selo, which developed by the late $19^{\text {th }}$ - early $20^{\text {th }}$ centu- 
ries when two-storey private houses of country architecture prevailed in it.

The conducted research corrects the inaccurate information about the sequence of ownership, building history, authorship, and the original appearance of the lost historical building, present in the scientific and local history literature, before its destruction during the war years and subsequent restoration according to a standard design.

It was established that A.Ton, attributed to the project's authorship, was to guide the house's design and construction according to a model project.

After rebuilding according to architect V.Sokolov's project by order of E.Friderici, the house's historical appearance, made in the style of romantic classicism, as a characteristic element of the background development of Tsarskoye Selo of the early $20^{\text {th }}$ century is re-establish.

The loss of the house's original architecture is traced, its changes during the post-war restoration according to the standard design are revealed.

New data supplementing and clarifying information about the nature of the background development of Tsarskoye Selo can serve as the basis for restoring the lost house and building elements of the site, which will enable to recreate a genuine corner of the old city in the future, illustrating the lost appearance of the residential areas of Tsarskoye Selo.

\section{REFERENCES}

1. Archive of the State Unitary Enterprise GUION of St. Petersburg. Branch of CC "Iugo-Vostochnoye". Pushkin, St. Krasnaya Zvezda, 21. Scheme of the yard sewage system, 1948.

2. Archive of the State Unitary Enterprise GUION of St. Petersburg. Branch of CC "Iugo-Vostochnoye". Pushkin, St. Krasnaya Zvezda, 21. Technical passport of the house, 1960.

3. Archive of the State Unitary Enterprise GUION of St. Petersburg. Branch of CC "Iugo-Vostochnoye". Pushkin, St. Krasnaya Zvezda, 21. Technical passport of the house, 1990.

4. RGIA F. 485. Inv. 3. f. 1021.

5. RGIA F. 487. Inv. 4. f. 194.

6. Technical archive of LLC Lenzhilniiproekt. Technical Report on the Inspection of Structures of the House Number 21 on St. Krasnaya Zvezda in Pushkin. 1984.

7. TsGA St.Petersburg, F. 4958. Inv.1. f. 40.

8. TsGA St.Petersburg, F. 4958. Inv.1. f. 128.
9. TsGA St.Petersburg, F. 4958. Inv.1. f.197.

10. TsGA St. Petersburg F. 8557. Inv. 6. f. 373.

11. TsGIA St.Petersburg, F. 1546. Inv. 2. f. 5862.

12. TsGIA St.Petersburg, F. 1546. Inv. 5. f. 1809.

13. Kuptsov I.V. The Stroganov Family. Chelyabinsk. 2005.

14. Moschenkova, M.A., Kornilova, N.A. 2010. Historical Buildings of Tsarskoe Selo. Historical Sketch of Urban Development (18 $8^{\text {th }}$ - Early 20 $0^{\text {th }}$ Century), St.Petersburg,

15. Semenova, G.V. 2009. Tsarskoe Selo: Familiar and Unfamiliar. Moscow, TsenterPolygraph,

16. Tsarskoe Selo of Anna Akhmatova. Addresses. Developments. People. Literary and Historical Excursion with Sergei Senin Through Poetry, Memoirs, Diaries, Photographs, Postcards and Other Documents of the Era. St.Petersburg, 2009.

17. Tsylov, N.I. 1858. Atlas of Tsarskoe Selo, St.Petersburg,

18. Family Unions Without a Royal Blessing. Part II. [Web resource] Access code: http://russculture.ru/2018/04/02/ семейные-союзы-без-монаршего-благосл-2/ 
Рафаэль Маратович Даянов

преподаватель кафедры архитектуры

Санкт-Петербургского государственного

академического института живописи,

скульптуры и архитектуры имени И.Е. Репина,

архитектор-реставратор высшей категории,

Заслуженный строитель Российской Федерации,

Почётный архитектор РФ,

Почётный реставратор Санкт-Петербурга; директор Архитектурного бюро «Литейная часть - 91», e-mail: raf_dayanov@mail.ru

Санкт-Петербург, Россия

ORCID 0000-0002-8950-0698

Анна Михайловна Залманзон научный сотрудник Балтийской реставрационной коллегии; e-mail: zalmanzon@mail.ru Санкт-Петербург, Россия

ORCID 0000-0002-5099-4301

DOI: 10.36340/2071-6818-2020-16-4-75-91

\section{ДОМ ФРИДЕРИЦИ - УТРАЧЕННЫЙ ЭЛЕМЕНТ ФОНОВОЙ ЗАСТРОЙКИ ЦАРСКОГО СЕЛА}

\section{Аннотация:}

Статья посвящена истории строительства и архитектуре утраченного элемента типичной исторической рядовой застройки Царского Села - дома с современным адресом г. Пушкин, ул. Красной Звезды 21. Дом, построенный в 1838 г., подвергся большому числу перестроек и полностью утратил свой первоначальный облик, однако находится на месте постройки. На основании архивных материалов нам удалось установить последовательность перестроек и особенности архитектуры здания в разные годы его существования. Установлены имена архитекторов, участвовавших в проектировании и строительстве, а также сведения о владельцах дома в разные временные периоды. Так, ранее считалось, что первоначально дом принадлежал вдове Фридерици. Нашими архивными исследованиями установлено, что до неё у дома было, по крайней мере, два владельца. Генеалогические исследования позволили установить личность Елизаветы Фридерици, которая была последней в дореволюционный период, а не единственной владелицей дома. Статья иллюстрирована впервые публикуемыми историческими чертежами и рисунками. Приводятся имена архитекторов, участвовавших в проектировании (И.А. Резанцев, А.А. Тон и др.). На основе рисунков и чертежей дается подробное описание здания. Прослеживаются перестройки здания, особенно детально перестрой- ка по проекту В.Д. Соколова 1909 - 1910 гг. Судьба зданий фоновой застройки сложилась трагически. Во время Великой отечественной войны г. Пушкин был оккупирован. Было разрушено 85\% этих зданий, а сохранившиеся нуждались в большом ремонте. В 1947 г. бывший дом Фридерици был заново построен в стиле советского классицизма, его изначальный облик его был сильно искажен. Приводится критический анализ архитектуры здания. В 1960 г. дом был капитально отремонтирован. После ремонта, как подтверждает проектная и техническая документация полностью утрачена историческая планировка здания. Градостроительная ценность рассматриваемого дома определяется тем, что здание сохраняет масштаб исторической фоновой застройки. Остальные элементы, определяющие его градостроительную значимость, утрачены. Несмотря на сохранность некоторых исторических характеристик (масштаб постройки и композиционные приемы лицевого фасада), объект не может считаться источником информации о развитии культуры, так как в результате разрушения в годы войны и последующего восстановления утратил аутентичный исторический облик.

Ключевые слова: дом Фридерици, фоновая застройка, Царское село, архитектор А. А. Тон, архитектор И. А. Резанцев, архитектор В. Д. Соколов, исторические объекты. 
Дом № 21 по улице Красной Звезды в городе Пушкине является одним из немногих сохранившихся планировочных элементов первоначальной рядовой застройки Царского Села.

Г.В. Семёнова, впервые введшая информацию о здании в научный оборот, указала в своей книге, что дом был построен по проекту архитектора А.А. Тона в 1838 году для жены офицера гусарского полка Е.Р. Фридерици, а в 1909 году его перестроил архитектор В. Соколов для А.А. Григорьевой. При этом, по мнению исследовательницы, дом до наших дней сохранил характер архитектуры в стиле позднего классицизма. [15]. Иные данные о здании в литературе отсутствуют. Эти сведения приводятся во всей краеведческой литературе, изданной после опубликования книги Г.В. Семёновой, а также внесены в учётные данные Комитета по государственному контролю, использованию и охране памятников истории и культуры (КГИОП).

В ходе историко-архивного исследования, предпринятого в целях изучения детальной истории дома, были установлены факты, уточняющие данные о владельцах и перестройках здания. В архивах найдены чертежи, полностью меняющие представление об утраченном в результате разрушения в годы оккупации и последующего восстановления историческом облике постройки в дачный период Царского Села.

Фоновая застройка Царского Села почти полностью утрачена в период гражданской, Великой Отечественной войн и оккупации. Реконструированный на основании архивных данных облик рассматриваемого дома являлся типичным образцом рядовой застройки Царского Села в его дачный период конца XIX - начала XX в. Новые данные об архитектуре здания позволяют дополнить представление о сохранившемся лишь в немногочисленных изображениях, облике кварталов рядовой застройки Царского Села. Открытия, сделанные в ходе исследования, восстанавливают истину в части подлинного облика почти полностью утраченного здания, которое в его нынешнем непрезентабельном облике, признаваемом литературой за подлинный, искажает представление о фоновой застройке жилых кварталов царской резиденции.

Участок для застройки дома, расположенного на участке с современным адресом г. СанктПетербург, г. Пушкин, ул. Красной Звезды, 21 был отведён в 1830-х годах. Участок значился по улице Стессельской, 3-й части Царского Села - Софийского предместья, распланированной по проекту архитектора А.П. Гильденбрандта, утверждённому в 1832 году [14]. Застройка обывательскими домами на месте бывшего города Софии по проекту планировки кварталов архитектора А.П. Гильденбрандта 1832 года предполагалась по образцовым проектам. Лицевой дом на участке построен в 1838 году. Полностью перестроенный и утративший свой исторический облик этот первоначальный дом сохраняется до настоящего времени на своём первоначальном месте.

На основании вновь найденных архивных материалов устанавливается последовательность владельцев данного участка. Уточнённые данные опровергают ранее принятую в литературе атрибуцию первоначального здания, как принадлежавшего жене офицера Е.Р. Фридерици. Архивные материалы однозначно свидетельствуют, что первой владелицей участка и заказчицей лицевого дома была жена титулярного советника Ольга Григорьева.

Следующей по времени, после Григорьевой, владелицей участка, о которой сохранились сведения, является жена майора Мария Яковлевна Михайлова [17, С.71].

В семье Михайловых участок находился до 9 декабря 1906 года, когда на публичных торгах от дочери генерал-лейтенанта Ольги Григорьевны Михайловой он перешёл к провизору Альфонсу Ивановичу Дерингеру. 3 февраля 1907 года Дерингер продал участок со всеми строениями жене штаб-ротмистра Е.Ф. Фридерици [11].

На основании изучения литературы по генеалогии установлена личность Фридерици, чье имя в литературе было необоснованно присвоено первому владельцу участка. Это последняя в царский период, а не первая владелица участка - Елизавета Фабрициевна Фридерици, ур. герцогиня Руффо (1887-1940) - дочь княжны Натальи Александровны Мещерской и ее мужа, рыцаря Мальтийского ордена, итальянского герцога Фабрицио Сассо-Руффо. В первом браке (1907-1916) - за полковником гвардии Александром Александровичем Фридерици, во втором (с 1918) - за князем императорской крови Андреем Александровичем Романовым [13, С. 139].

Первая владелица участка жена титулярного советника Ольга Григорьева около 1839 года өна 
выстроила на участке одноэтажный с мезонином дом на семь осей по лицевому фасаду [4].

Рис. 1. Архитекторы И.А. Резанцев, А.А. Тон. Дом титулярной советницы Ольги Григорьевой. План и фасад. 1838 г. РГИА. Ф. 485. Оп. 3. Д. 1021. Л. 1.

На вытянутом участке прямоугольной формы по проекту должен был быть построен деревянный лицевой дом на семь осей, одноэтажный с мезонином. Со стороны двора к основному объёму дома примыкали галереи, тянувшиеся вдоль всего фасада. Далее, в сторону двора к галереям был пристроен прямоугольный в плане объём кухни и объём ретирадника. На участке, в глубине, разбивался сад с центральной деревянной, квадратной в плане беседкой. В центре участка, у сада, располагались сараи с конюшнями, навозной и помойной ямами, ретирадником. От улицы участок отделялся глухим забором с воротами.

Лицевой фасад дома под скатной крышей с центральным ризалитом, увенчанным треугольным фронтоном, по композиции близок к образцовым проектам классицизма, однако в деталях прослеживается влияние зарождающегося романтизма.

Оформляющие края ризалита пилястры стилизованные, филёнчатые - завершаются плитой вместо капители. Поле ризалита дробно разделено вертикальными и горизонтальными членениями. Кроме угловых пилястр, ризалит оформлен узкими пилястрами в простенках в уровне каждого этажа. Этажи разделены широкой тягой, имеющей подчёркнуто пластичное решение: филёнку-нишу, обрамлённую дополнительным уступом. Подоконные пространства оформлены рядами балясин. Фасад венчается профилированным карнизом. Под фронтоном расположен гладкий фриз.

На чертеже сохранились правки одного из проверяющих. Кто-то (скорее всего, А.А. Тон) не согласился с междуэтажной тягой-филёнкой, она зачёркнута. Гладкий фриз правками предложено украсить орнаментом, а также изменить рисунок забора и форму ворот.

Рис. 2. Архитекторы И.А. Резанцев, А.А. Тон. Дом титулярной советницы Ольги Григорьевой. Фрагмент. 1838 г. РГИА. Ф. 485. Оп. 3. Д. 1021. Л. 1.
Проект был Высочайше утверждён 9 февраля, в 183(?) года. Последняя цифра в написании года оборвана. Судя по другому документу архива, дом был построен к 1839 году. В данном деле говорится об освидетельствовании печей по проекту Шарлеманя в данном доме в январе 1840 г. [5]

В литературе авторство здания приписывается архитектору A.A. Тону. В проектном чертеже постройки нет указания на его авторство. Надпись на проекте гласит, что его «чертил Иван Резанцов», а проверил Тон: «Смотрено Архитектор А. Тон». Такая формулировка позволяет утверждать, что при проектировании архитектор И. Рязанцев пользовался образцовым проектом, который он взял за основу. Как главный архитектор Царского Села А.А. Тон руководил проектированием дома, также как и всей другой частной застройкой города, и согласовал данное проектное решение.

В 1858 году на участке, отделённом от улицы забором, находился первоначальный одноэтажный деревянный дом на каменном фундаменте [17, С. 71].

За время владения участком семьи Михайловых на участке были выстроены несколько служебных деревянных построек [11]. Деревянный одноэтажный с мезонином лицевой дом сохранялся в первоначальном виде.

Провизор Альфонс Иванович Дерингер, ставший хозяином участка после дочери генерал-лейтенанта Ольги Григорьевны Михайловой 9 декабря 1906 года, владел им всего два месяца, а затем продал участок со всеми строениями жене штаб-ротмистра Е.Ф. Фридерици.

В 1909 году лицевой дом по заказу Е.Ф. Фридерици был надстроен вторым этажом, к нему была сделана пристройка со стороны двора. Автор проекта - архитектор В.Д. Соколов (1889-1955 fг), в будущем - известный советский архитектор [12].

Рис. 3. Архитектор В.Д. Соколов. Дом жены штаб-ротмистра Лейб-гвардии Гусарского Его Величества полка Е.Ф. Фридерици. Фасад. 1909 г. ЦГИА СПб. Ф. 1546. Оп. 5. Д. 1809. Л. 16-17.

При перестройке была разобрана северная, дворовая часть лицевого дома (галерея с кухней), на их месте выстроен новый двухэтажный объём с выступом в сторону восточного фасада, предназначенный для расширения квартир и 
организации второй лестницы. К моменту перестройки вход в здание и лестничная клетка были организованы со стороны западного фасада. По проекту В.Д. Соколова организовывалась вторая лестница в квартиры, со стороны восточного фасада. В интерьерах выполнены локальные перепланировки с организацией подсобных помещений и дополнительных санузлов, а также с разделением квартир на господскую (у лицевого фасада) часть и зону прислуги (у дворового фасада, со входом с восточного фасада).

Фасад был перестроен с оформлением в стиле неоклассицизма. Оштукатуренный фасад, сохранивший структуру предшествующей постройки с выделенной пилястрами центральной частью под треугольным фронтоном, имел богатое оформление. Мелкий масштаб фасадного декора придавал зданию характерный для фоновой застройки Царского Села «дачный» вид.

От предшествующей постройки архитектор сохранил центральный ризалит под треугольным фронтоном, оформленный по углам филёнчатыми пилястрами, тонкие пилястры между окнами второго этажа в поле ризалита, оформление подоконных ниш рядами балясин. Пилястрами с филёнками архитектор оформил также края лицевого фасада. К оформлению всех пилястр зодчий добавил стилизованные орнаментальные капители. В пространстве между окнами первого и второго этажа автор добавил прямоугольные филёнки, гладкие в боковых частях фасада и орнаментированные в ризалите. Полукруглое окно мансарды под высокой крышей, оформленное рустом, ограждение кровли из металлических решёток геометрического орнамента между столбиками, штукатурка, имитирующая обшивку деревянного дома, - довершили новый камерный облик дачного особняка в характере неоклассицизма. Таким образом, при перестройке фасада архитектор использовал не только его композицию, заданную образцом классицизма, но и наиболее интересные элементы декора предшествующей постройки: филёнчатые пилястры, ряды балясин в подоконных нишах. В архитектуре фасада прослеживается преемственность, однако в трактовке усилено романтическое начало. Лёгкими приёмами, не требовавшими значительных переделок, автору удалось переосмыслить архитектуру фасада, полностью отойдя от официозного классицизма, и изменив его звучание.
Тот факт, что чертёж лицевого фасада был принят в 1914 году Петроградским губернским банком как документ для оценки недвижимости, а кредит был одобрен и выдан [11, Л. 14-15], свидетельствует о том, что представленный проектный чертёж представлял выполненную в натуре постройку. Фасады дома были оштукатурены, что зафиксировано актом осмотра дома для залога $[11$, Л. 8].

Так как дерево было материалом более дешёвым, чем кирпич, такой приём обеспечивал владелице экономию средств, при этом создавал полную иллюзию богатого каменного дома.

K моменту перестройки на участке сохранялся сад с беседкой, сарай с конюшней, а также были выстроены новые служебные постройки и деревянный ледник [12, Л. 3].

Рис. 4. Архитектор В.Д. Соколов. Дом жены штаб-ротмистра Лейб-гвардии Гусарского Его Величества полка Е.Ф. Фридерици. План участка. 1910 г. ЦГИА СПб. Ф. 1546. Оп. 5. Д. 1809. Л. 2 об.

В 1910 году одна из новых построек - деревянный дворовый флигель за лицевым домом (восточный) был надстроен вторым этажом и расширен пристройкой. Фасады деревянной постройки были обшиты досками. Архитектор оформил фасады флигеля в неорусском стиле. Тогда же был построен новый служебный (с жилой квартирой) одноэтажный бревенчатый флигель с мезонином.

Рис. 5. Архитектор В.Д. Соколов. Дом жены штаб-ротмистра Лейб-гвардии Гусарского Его Величества полка Е.Ф. Фридерици. Фасад флигеля лит. Б. 1910 г. ЦГИА СПб. Ф. 1546. Оп. 5. Д. 1809. Л. 8-9.

Нарядный лицевой дом в стиле романтического неоклассицизма и деревянные дворовые флигели в неорусском стиле были призваны создать единый ностальгический ансамбль «усадьбы в миниатюре».

Участок с постройками был заложен в Петербургском областном губернском банке в 1914 году. В описании для залога сказано, что все здания построены около 6 лет назад, прочные. В отчёте архитектора, проводившего оценку зданий, отмечена особая прочность постройки 
и солидность отделки всех домов, позволившая оценить их значительно дороже обычной залоговой стоимости [11].

Рис. 6. Архитектор В.Д. Соколов. Дом жены штаб-ротмистра Лейб-гвардии Гусарского Его Величества полка Е.Ф. Фридерици. Фасад флигеля лит. С. 1910 г. ЦГИА СПб. Ф. 1546. Оп. 5. Д. 1809. Л. 10-11.

В первой половине XX века застройка участка сохранялась, на нём существовали возведённые в 1909-1910 гг. лицевой дом и два дворовых флигеля.

Владелица дома Е.Ф. Фридерици во время февральского переворота 1917 года оказалась в Крыму, куда она поехала за своим возлюбленным, Великим Князем Андреем Александровичем. В 1918 году супруги покинули Россию [18].

В период граджданской войны началась утрата фоновой застройки Царского Села, которое на три дня было захвачено армией Юденича. Именно тогда в городе сгорело большое количество жилых домов. Об этом событии А.А. Ахматова пишет в незавершённой поэме «Русский Трианон»:

Все занялись военной суетою,

И от пожаров сделалось светло.

И только юг был залит темнотою.

На мой вопрос, с священной простотою

Сказал сосед: «Там Царское Село.

Оно вчера, как свечка, догорело».

И спрашивать я больше не посмела» [16].

В ходе Великой Отечественной войны, 18 сентября 1941 года, город был захвачен немецкими войсками. Начался длительный период оккупации. Захватчики уничтожили и повредили многие сооружения дворцового ансамбля, вывезли произведения искусства.

От действий оккупантов сильно пострадало гражданское население и жилой фонд. Почти все жители города были перемещены в лагеря, вывезены на работы в Германию или убиты. Дома Пушкина опустели. В результате оккупации во время Великой Отечественной войны жилая застройка Пушкина полностью утрачена на 85 \%, оставшиеся 15 \% жилых домов имели серьёзные повреждения и требовали «большого ремонта» [7, Л. 27].

Лицевой дом по ул. Красной Звезды, 21 во время войны также сильно пострадал. Из документов известно, что довоенный владелец дома - Василий Иванович Чекулаев - потерял во время оккупации Пушкина жилой дом объёмом 5000 кв. метров, надворную постройку, лошадь, свинью и домашних птиц. Потери в жилых и служебных зданиях на участке выразились в сумму 430000 рублей [10, Л. 54-54 об.].

Дворовые флигели были разрушены, о чём свидетельствует план участка 1948 года, зафиксировавший на месте дореволюционных дворовых построек фундаменты, совпадающие по конфигурации с постройками на плане 1914 года [1].

После войны, в 1947 году, полуразрушенный дом был восстановлен.

В титульном списке капитального строительства Пушкинского районного исполкома на 1947 год дом по адресу ул. Красной Звезды, 21 значится как объект капитального строительства со сметной стоимостью 22, 5 тыс. рублей и сроком окончания работ во втором квартале года $[8$, Л. 102-102 об.].

Восстановленный жилой дом взят на баланс Производственного ремонтно-эксплуатационного объединения Пушкинского райисполкома 1 марта 1947 года [3].

Фасадам восстановленного дома придали оформление в духе советского классицизма. Для советского понимания стиля характерно использование декоративных деталей классицизма в отрыве от их архитектонического смысла: тяга в верхней части фасада сливается с верхней линией наличников, замковые камни над окнами второго этажа вторгаются в поле антаблемента, руст по краям ризалита выполнен только в уровне второго этажа, полукруглые ниши над окнами первого этажа одновременно трактованы как архивольты, но при этом их пяты ни на что не опираются, «подвешены»в простенках. Сами ниши различаются по габаритам, так же, как и расположенные под ними простенки между центральными окнами. Не прослеживается система в оформлении боковых фасадов: окна разных размеров и пропорций, имеются нарушения положения в осях, наблюдается сильный разнобой в ритме простенков и проёмов.

Сухой главный фасад советского времени с ориентацией на официозный классицизм резко контрастирует с трактовками исторических фасадов 1839 и 1909 годов, в которых были 
преемственно использованы приёмы смягчения и романтизации облика загородного частного дома.

Рис. 7. Фасад дома № 21 по ул. Красной Звезды в г. Пушкине. Фото 2018 г.

По сути, оформление советских фасадов рассматриваемого дома нельзя даже отнести к классицизму, - слишком поверхностное и искажённое понимание стиля вложено в их создание. Из документов послевоенного восстановления пушкинских домов известно, что после ремонта домам придавали оформление по типовым проектам [9, Л. 14].

В 1960 году, согласно данным техпаспортов, в доме был произведён капитальный ремонт. Сохранившиеся документы свидетельствуют о том, что капремонт заключался в перепланировке. Было уничтожено крыльцо на восточном фасаде, на месте вестибюля и лестничной клетки в этой части распланированы квартиры. Историческая планировка дома, судя по планам 1960 года, при перестройке была полностью утрачена. Дом разбит на несколько квартир коридорного типа, тогда как первоначальный исторический дом имел анфиладную планировку [2].

Укрепление конструкций в 1960 году не производилось, об этом можно судить на основании данных обследования строительных конструкций, проведённого спустя 24 года. В 1984 году институт «Ленжилпроект» по результатам обследования выдал заключение о неремонтопригодности дома и рекомендовал его к разборке [6].

Градостроительная ценность рассматриваемого дома определяется тем, что здание сохраняет масштаб исторической фоновой застройки. Остальные факторы его градостроительной значимости утрачены. За исключением частично сохранившегося рассматриваемого лицевого дома и бетонного ледника, участок утратил историческую застройку. Историческое межевание не сохранилось. Лицевое здание сохраняется в сильно искажённом перестройками виде. Его внешний облик в духе советского казённого классицизма даёт искажённое представление о фоновой застройке Царского Села. Здание не отражает ни императорский период образцовой застройки эпохи Николая I, ни эпоху «дачного бума» с уютным дачным особняком в стиле неоклассицизма.
Здание сохраняет основные приёмы композиции лицевого фасада исторического здания: количество осей (7), местоположение центрального ризалита и форму завершения треугольный фронтон. Форма плана и габариты фасадов относятся к периоду перестройки 1909 года, когда первоначальное здание, построенное по образцовому проекту в 1838-1839 годов, было надстроено вторым этажом, перестроено со стороны дворового фасада и расширено прямоугольным выступом с восточной стороны.

Оштукатуренный фасад, сохранивший структуру предшествующей постройки с выделенной пилястрами центральной частью под треугольным фронтоном, имел оригинальное архитектурное оформление. Мелкий масштаб фасадного декора придавал зданию характерный для фоновой застройки Царского Села начала XX века «дачный» вид. При перестройке фасада архитектор использовал не только композицию фасада, заданную образцом классицизма, но и наиболее интересные элементы декора предшествующей постройки: филёнчатые пилястры, ряды балясин в подоконных нишах. В архитектуре фасада прослеживается преемственность с первоначальной постройкой, однако в трактовке усилено романтическое начало. Таким образом, как элемент фоновой застройки Царского Села перестроенный дом представлял собой тип провинциального особняка, близкого по архитектуре к двухэтажным дачным домам и небольшим особнякам, преобладавшим в застройке Царского Села начала XX века.

Существующий в настоящее время лицевой фасад появился в результате восстановления дома после войны в 1947 году. В результате разрушения дома и его последующего восстановления утрачены наиболее выразительные элементы фасада, смягчавшие звучание строгого классицизма и придававшие фасаду черты романтизма.

При воссоздании дома была изменена форма и высота крыши, мансардный этаж не восстанавливался. В результате работ по восстановлению и многочисленных последующих перепланировок утрачена историческая планировка дома.

Таким образом, рассматриваемое здание утратило ценностные характеристики: подлинную архитектуру фасадов, планировку, высотные габариты.

Несмотря на сохранность некоторых исторических характеристик (масштаб постройки 
и композиционные приёмы лицевого фасада), объект не может считаться подлинным источником информации о развитии культуры, так как в результате разрушения в годы войны и последующего восстановления утратил подлинный исторический облик. Существующий в настоящее время лицевой дом с уродливым фасадом советского периода искажает представление о рядовой застройке Царского Села, сложившейся к концу XIX - началу XX века, когда в ней преобладали двухэтажные частные дома дачной архитектуры.

Проведённые исследования исправляют присутствующие в научной и краеведческой литературе недостоверные сведения о последовательности владения, строительной истории, авторстве и подлинном облике утраченного исторического здания до его разрушения в годы войны и последующего восстановления по типовому проекту.

Установлено, что доля участия А.А. Тона, которому приписывается авторство проекта, заключалась в руководстве проектированием и строительством дома по образцовому проекту.

Восстанавливается исторический облик дома, после перестроек по проекту архитектора В.Д. Соколова по заказу Е.Ф. Фридерици, как характерного элемента фоновой застройки Царского Села начала XX века, выполненного в стиле романтического классицизма.

Прослежены утраты подлинной архитектуры дома, выявлены её искажения в ходе послевоенного восстановления по типовому проекту.

Новые данные, дополняющие и уточняющие сведения о характере фоновой застройки Царского Села, могут послужить основанием для восстановления утраченного дома и элементов застройки участка, что позволит в дальнейшем воссоздать подлинный уголок старого города, иллюстрирующий утраченный облик жилых кварталов Царского Села.

\section{БИБЛИОГРАФИЯ}

1. Архив ГУП ГУИОН Санкт-Петербурга. Филиал КЦ «Юго-Восточное». Пушкин, ул. Красной Звезды, д. 21. Схема дворовой канализации. 1948 г.

2. Архив ГУП гУИОН Санкт-Петербурга. Филиал КЦ «Юго-Восточное». Пушкин, ул. Красной Звезды, д. 21. Технический паспорт дома 1960 г.

3. Архив ГУП ГУИОН Санкт-Петербурга. Филиал КЦ «Юго-Восточное». Пушкин, ул. Красной Звезды, д. 21. Технический паспорт дома 1990 г.

4. РГИА Ф. 485. Оп. 3. Д. 1021.

5. РГИА Ф. 487. Оп. 4. Д. 194.

6. Технический архив ООО «ЛенжилНИИпроект». Техническое заключение по обследованию конструкций дома № 21 по ул. Красной Звезды в г. Пушкине. Ленинград, 1984.

7. ЦГА СПб Ф. 4958. Оп. 1. Д. 40.

8. ЦГА СПб Ф. 4958. Оп. 1. Д. 128.

9. ЦГА СПб, Ф. 4958. Оп. 1. Д.197.

10. ЦГА СПб Ф. 8557. Оп. 6. Д. 373.

11. ЦГИА СПб Ф. 1546. Оп. 2. Д. 5862.
12. ЦГИА СПб Ф. 1546. Оп. 5. Д. 1809.

13. Купцов И.В. Род Строгановых. - Челябинск, 2005.

14. Мощенкова М.А., Корнилова Н.А. Историческая застройка Царского Села. Исторический очерк градостроительного развития (XVIII - начало XX века). - СПб., 2010.

15. Семёнова Г.В. Царское Село: знакомое и незнакомое. - М.: ЦентрПолиграф, 2009.

16. Царское Село Анны Ахматовой. Адреса. События. Люди. Литературно-историческая экскурсия с Сергеем Сениным по стихам, воспоминаниям, дневникам, фотографиям, открыткам и другим документам эпохи. - СПб., 2009.

17. Цылов Н.И. Атлас города Царского Села. - СПб., 1858.

18. Семейные союзы без монаршего благословения. - Ч. II [Электронный ресурс]. http://russculture. ru/2018/04/02/семейные-союзы-без-монаршего-благосл-2/ 